\title{
Reverse Dutch Disease and Mineral Exporting Developing Economies
}

\author{
David Evans
}

\section{Introduction}

At various times over the last 15 or 20 years, most mineral exporters have experienced periods of sustained boom from their mineral exports, either through a peak in mineral commodity prices, or from a general expansion in their mineral exporting capacity. It became fashionable to refer to the effects of such export booms as the 'Dutch Disease', a term coined in the late 1960 s when it was realised that the boom in natural gas exports from the Netherlands was a mixed blessing because of the difficult macro and structural adjustment problems which resulted. With generally adverse conditions in the world economy since the end of the 1970s, the Dutch Disease problems are now more likely to be seen in reverse.

The typical reverse Dutch Disease problems for mineral exporters are both macro and micro. The macro adjustment problem appears as a combination of required real exchange rate, real wage rate and government expenditure changes. The micro adjustment problem appears at the sectoral level through the impact of changes in the pattern of comparative advantage produced by the mineral export slump. The particularly difficult set of policy decisions which now face mineral exporting developing countries revolve around how these macro and micro adjust ments are to be managed in the short-run whilst maintaining a coherent medium and long-run development strategy.

The inherited framework within which Dutch Disease and reverse Dutch Disease problems have been analysed has been heavily influenced by a class of economic models called the specific factors model.' These models focus on two types of commodities produced in an economy, tradeables and nontradeables, and two types of resources, sector-specific resources such as mineral deposits or other natural resources with limited transferability to alternative

\footnotetext{
1 The specific factors model stems from Jones (1971) and Samueison (1971). For a discussion of its application to the analysis of export booms, see Corden and Neary (1982).
}

uses, and labour as a generally mobile resource used in all sectors. In these models the key relative prices which must change as a part of the adjustment process are the real exchange rate (the price of tradeables relative to non-tradeables) and the real wage rate. The major structural changes required are shifts in the allocation of labour between sectors and, insofar as changes in the fortunes of mineral exports affect government revenue, there must be a flexible response of government expenditure.

The specific factors model is both simple and powerful, but is standard form. It needs two important sets of modifications before it is suitable for application to the medium and long-run problems of mineral exporting developing countries. First, although real wage changes may well be a part of a reverse Dutch Disease adjustment process, few developing country governments are prepared to allow full market clearance on the labour market in the modern or capitalistic sectors of their economies. Also, income-sharing institutions prevailing in the traditional or non-capitalist sectors will often govern the opportunity costs of labour which is mobile between the traditional and capitalistic sectors. Second, in the long-run, it is important from a private and a public perspective to focus on the intersectoral re-allocation of scarce capital in the structural adjustment process and in the formulation of development policy and strategy.

In section II, I describe a longer-run specific factors model which has both mobile labour and capital, with an institutional wage determining the returns of labour. This model is illustrated in section III through an analysis of some aspects of trade policy and strategy facing Papua New Guinea, a typical mineral developing country facing reverse Dutch Disease problems. For the most part, I will focus almost entirely on the resource re-allocation side of the longer-run adjustment process arising from relative price changes, leaving aside expenditure adjustments.

IDS Bulletim, 1986, vol 17 no 4, Institute of Development Studies, Sussex 


\section{A Longer-run Dutch Disease Model}

Suppose that there are three types of tradeable commodities produced commercially or under capitalist relations of production - 'mineral', 'agricultural' and 'manufacturing' commodities. In non-tradeable production, 'services' are produced capitalistically whilst 'traditional agricultural' commodities are produced in the non-capitalist sector. In all capitalistic sectors, production requires some kind of sector-specific resource - mineral resources, agricultural land with attendant infrastructure, urban land with infrastructure suitable for manufacturing activity, urban land suitable for services, and land used in traditional agriculture. In addition, the capitalist sectors require both mobile capital and labour. Capital in this context can best be thought of as the stock of reproducible commodities required in production - raw materials and other intermediate inputs, and machinery and equipment. For the most part, labour will be treated as if it is homogeneous or without skill differentiation. It will be assumed throughout that there will be diminishing returns to additional amounts of both physical capital and labour when applied to a fixed amount of a specific factor. Little attention will be paid to labour mobility between the captitalistic and non-capitalist sectors so that the institutional wage will refer to the capitalistic sector. In so far as the non-capitalist sector produces non-traded agricultural commodities, this simplication will not be of too much consequence for present purposes.

Consider now the consequences of a longer-run change in the price of mineral exports with constant world prices of tradeable agricultural and manufacturing commodities. This will have direct effects in the mineral export sector, as well as powerful indirect effects through the change in foreign exchange availability on the rest of the economy.

If real wages are fixed in terms of some bundle of tradeable and non-tradeable commodities and if mineral commodities play no role as reproducible capital, the full impact of the direct effects of a decline in mineral export prices will be a fall on mineral resource rents and the returns to capital: mineral resource rents will decline absolutely in terms of all prices, and the returns to capital will decline in terms of mineral prices. To the extent that some of the wage is paid in terms of non-tradeables, there will be an offset to the fall in mineral rent and returns to capital, but it is unlikely that this will be sufficient to reverse the direction of change since the mineral sector is likely to be highly capital and resource intensive. In the non-mineral economy, there will be important relative price changes but these will operate through the effects of the reverse Dutch Disease on foreign exchange availability.
As a result of a fall in the availability of foreign exchange, the economy will obtain fewer non-mineral tradeables relative to non-tradeables, so that there will be a rise in the price of non-mineral tradeables relative to non-tradeables. This is equivalent to a depreciation of the real exchange rate which can be achieved without a fall in the absolute price of non-tradeables through an adjustment of the exchange rate. The fall in the relative price of non-tradeables will lead to a fall in the rent on specific resources used in non-tradeables relative to all other prices and a rise in the returns to mobile capital in terms of non-tradeables. Rent on specific resources used in non-mineral tradeables will rise in terms of non-mineral tradeables to the extent that some wages are paid in terms of non-tradeables and will certainly rise in terms of all other prices. The returns to capital will fall in terms of non-mineral tradeables,${ }^{2}$ but rise or fall overall when the effects of mineral and non-traded activities are taken into account.

The above results for the changes in specific factor rents are entirely in line with the standard specific factors model with only mobile labour and a market clearing wage rate. At a fixed real wage rate, the entire burden of the indirect price adjustments falls on specific factor rent in non-tradeables and the returns to capital. Since the most important specific factor used in non-traded 'service' production is urban land, the indirect beneficiaries of the original Dutch Disease boom will have been the owners of urban land. Therefore from most perspectives, it would be readily agreed that it is appropriate that a major part of the reverse Dutch Disease adjustment should be borne by such property owners. Equally, such property owners could form a sufficiently important interest group opposed to adjustment by taking action which prevents a decline in the real exchange rate.

The direction and extent of the change in the returns to capital is not clear from the above analysis. Since the returns to capital decline in terms of the price of both minerals and tradeable agricultural and manufacturing prices, but may increase in terms of non-traded services the direction and extent of the change in the overall rate of profit will therefore depend on how large the mineral and agricultural and manufacturing sector is relative to the non-traded activities and on the extent to which indirect effects lead to an increase in the returns to capital in the non-mineral tradeables operating through non-traded service components entering into reproducible capital and the real wage bundle. However, since reproducible capital employed in the mineral sector is unlikely to be mobile within the

\footnotetext{
2 To the extent that non-traded commoditics are included in the wage bundle and in reproducible capital, the fall in the returns to capital in terms of non-mineral tradeables will be offset or even reversed, but these indirect effects are likely to be dominant.
} 
typical mineral exporting economy, either because it is foreign owned or because the sector is state owned with no institutional arrangements to allow for intersectoral capital mobility, the fall in the returns to mineral capital will often be isolated from the nonmineral economy. In this case, the direction and extent of the change in the returns to capital will depend on the size of non-traded service activities relative to traded agricultural and manufacturing activities and on the strength of any indirect effects.

The above analysis assumed that the real exchange rate depreciation required by the reverse Dutch Disease effects could be accommodated without a decline in real wages. However, for a large decline in the long-run mineral export prospects, this is unlikely to be sufficient. For most conceivable stylised facts about an economy, non-mineral tradeables will have a lower labour to capital intensity compared to nontraded services. Thus, a lowering of the real wage will facilitate a further decline in the price of nontradeables relative to tradeables. It will also increase both the general rate of profit and specific factor rent, all other things being equal.

In so far as reverse Dutch Disease has an impact on resource allocation through relative price changes, the results of the above analysis can be summarised as follows. On the production side, there will be an incentive for both mobile labour and capital to move from minerals and non-traded services into traded agricultural and manufacturing activities provided the elasticities of substitution are low. On the expenditure side, there will be an incentive to switch into the consumption of non-tradeables. From the point of view of longer-run adjustment policy, how much of the burden of adjustment will have to be borne by the owners of capital and specific resources in the minerals sector, the owners of specific resources in the nontraded sector, and the returns to non-mineral capital and wages, will depend crucially on the extent to which the adjustment can be made without a real wage change. Once real wage changes are introduced, adjustment costs will be shared among the owners of specific resources in mineral and non-traded activities, with a further increase in specific factor rents in nonmineral tradeable activities. It may even be possible for the non-mineral rate of profit to rise if the service sector is sufficiently large and the indirect effects described above are sufficiently powerful.

From the viewpoint of the formulation of trade strategy and policy in response to reverse Dutch Disease, the above analysis leaves out two crucial dynamic aspects of adjustment. First, it assumes that the supply of both specific factors and capital is fixed. Second, it ignores the possibility that a longer run development policy response to reverse Dutch Disease will involve productivity-enhancing technical change. Since a real wage decline is difficult to achieve politically, and is undesirable from most perspectives, it is important to consider the extent to which these dynamic considerations can assist in the longer-run adjustment to the reverse Dutch Disease. These possibilities can only be explored in a specific policy context which is taken up in the next section.

\section{Some Aspects of Trade Strategy and Policy}

In making some remarks on trade strategy and policy, I have in mind some of the reverse Dutch Disease problems facing a small predominantly mineral exporting developing country such as Papua New Guinea (PNG). In this case, the reverse Dutch Disease effects from mineral exports (and from a smaller but nevertheless important agricultural export sector) have been compounded by a lowering of Australian aid since independence. ${ }^{3}$ One of the policy responses to this in the short-run has been a modification of the wage-fixing arrangements so that not all of the increase in prices is compensated for in wage changes. More drastic measures involving directly administered real wage cuts have also been considered. ${ }^{4}$ Whilst wage cuts may be an important part of the short-run adjustment, it is unlikely that they would be widely accepted unless placed in the context of a longer-run perspective.

Two types of import substitution policies might be considered in PNG in the longer-run which may enhance the capacity of the economy to achieve the level of income expected by PNG citizens in the immediate post-independence years.

\section{(i) Food import substitution}

A high share of food consumption outside of the PNG gift economy ${ }^{5}$ is imported. There is therefore very considerable scope for import substitution in food. ${ }^{6}$ This will involve major new policy initiatives on two

\footnotetext{
${ }^{3}$ Ideally, lower bilateral Australian aid since independence was to have been offset by an increase in multilateral aid to PNG. However, in the face of the general decline in aid over the last 10 years or so, this has not taken place.

${ }^{4}$ For a discussion of the impact of real wage cuts on the real exchange rate in PNG, see Evans, Lucas and Daniel (1986).

"I refer to the non-capitalist subsistence economy as the gift economy for the reasons outlined in Gregory (1982). Although the internal structure of the PNG gift economy is very different from that of an independent peasantry producing and exchanging commodities, the type of non-capitalist economy which the original Lewis surpluslabour model principally referred to, the development of some commodity exchange at the margins of the gift economy has produced a limited a mount of labour power whose opportunity cost might be seen as the average level of material consumption available in the gift economy.

- Similar dependence on imported food can be found in many mineral exporting developing countries.
} 
fronts. First, the development of suitable land and infrastructure for such a new departure, both in the physical sense and in the social, institutional and organisational arrangements under which far greater quantities of land are transferred from the gift economy than has hitherto been contemplated. Such a policy would take advantage of the relative premium placed on specific factors employed in tradeable activities by the reverse Dutch Disease. If new institutional arrangements could be made whereby the form of organisation of such new sectors was cooperative, the benefits of the increased returns to the specific factors involved in terms of non-traded commodities would be more widely spread. Insofar as such import substitution improved productivity in food production, at least some of the costs of adjustment to the reverse Dutch Disease borne by wage-earners could be offset. ${ }^{7}$ Second, the effects of the reverse Dutch Disease on the price of traditional foodstuffs sold as commodities, relative to the price of tradeables, will be the same as for non-traded services (although the transmission mechanisms will be different). Thus, insofar as traditional non-traded food supplies are consumed by wage-earners in the capitalist economy, measures could be taken to enhance the consumption of such food and expand its availability outside of the gift economy. In the latter case, this will also involve new investment and organisation of food distribution, taking into account the social and institutional issues raised in the discussion of direct food import substitution. In effect, the policy towards enhancing the availability of traditional foodstuffs is aimed towards making traditional food more directly competitive with imported food ${ }^{8}$ To the extent that this is successful, the returns to traditional food production will rise in terms of tradeables.

\section{(ii) Manufacturing import substitution}

Manufacturing import substitution might be considered alongside food import substitution, but such a policy is more likely to be more difficult in mineral exporting developing countries for two reasons. First, precisely because of their history of successful mineral export activity, wages in the capitalist economy will be relatively high compared to developing countries less well endowed with natural resources. This, combined

\footnotetext{
Of course, a danger in food import substitution is that highly capital intensive food production systems are installed. If the capital intenslty of import substitute food production is higher than in other tradeable activities (after allowing for differential specific factor rents), then the purpose of the import substitution programme will be defeated. The same is true if food production requires significant protection, becoming, in effect, a non-tradeable activity.

8 I recognise that such a policy will entail a major shift in preferences towards traditional food. There is no reason why a a longer-run development strategy should not seek to dramatically influence the formation of consumer preferences and tastes.
}

with small internal markets, makes it more difficult to find commodities where simpler kinds of manufacturing import substitution can take place and where there is some reasonable prospect for eventual export capability. This suggests that it will be necessary to develop some specific skills and features in the manufacturing sector which will sustain eventual export production. The scope for such activities, already taken up to some extent in PNG through the manufacture of culture-specific artifacts, may be much more limited than the development of sector-specific resources for use in agricultural import substitution. This is particularly likely to be the case since both types of import substitution will be in competition for scarce organisational and other skills. It would therefore seem better to organise manufacturing import substitution around the linkage and servicing requirements of the agricultural import substitution policy.

\section{Concluding Remarks}

Implicit in discussion of trade strategy and policy in the context of the reverse Dutch Disease in mineral exporting developing countries was a judgement that the most scarce resources in such economies are capital and (less emphasised in the above discussion) organisational and other skills. It was in order to focus on a separate role for scarce capital and sector-specific resources that an alternative to the standard Dutch Disease models was developed. Since it is the supply of capital which is most severely constrained, both nationally and internationally in the present context, the importance of increasing the endowments of other resources by transforming available natural resources under the control of national governments, such as land with a potential for agricultural development, into new sector specific resources merits special consideration alongside the standard arguments for enhancing labour and organisational skills.

\section{References}

Corden, W. M. and J. P. Neary, 1982, 'Booming sector and de-industrialisation in a small open economy, Economic Journal, vol 92, (December), pp.825-48.

Evans, D., H. Lucas and P. Daniel, 1986, 'A mark-up model of price formation for the commodity economy of Papua New Guinea', IDS, University of Sussex, May

Gregory, C. A., 1982, Gifts and Commodities, Academic Press, London

Jones, R. W., 1971, 'A three-factor model in theory, trade, and history', in J. N. Bhagwati, R. W. Jones, R. A. Mundell and J. Vanek (eds.), Trade, Balance of Payments, and Growth: Essays in Honour of Charles P. Kindleberger, North-Holland Publishing Co., Amsterdam

Samuelson, P. A., 1971, 'Ohlin was right', Swedish Journal of Economics, vol 73, pp.365-84 